\title{
APPLICATION OF 6-NITROCOUMARIN AS A SUBSTRATE FOR THE FLUORESCENT DETECTION OF NITROREDUCTASE ACTIVITY IN Sporothrix schenckii
}

Cheila Denise Ottonelli STOPIGLIA(1,2), Mariana CARISSIMI(3), Tatiane Caroline DABOIT(1), Valter STEFANI(4), Valeriano Antonio CORBELLINI(5) \& Maria Lúcia SCROFERNEKER(1,6)

\begin{abstract}
SUMMARY
Introduction: Sporothrix schenckii is a thermal dimorphic pathogenic fungus causing a subcutaneous mycosis, sporotrichosis. Nitrocoumarin represents a fluorogenic substrate class where the microbial nitroreductase activity produces several derivatives, already used in several other enzyme assays. The objective of this study was the analysis of 6-nitrocoumarin (6-NC) as a substrate to study the nitroreductase activity in Sporothrix schenckii. Methods: Thirty-five samples of S. schenckii were cultivated for seven, 14 and 21 days at $35^{\circ} \mathrm{C}$ in a microculture containing 6-nitrocoumarin or 6-aminocoumarin (6-AC) dissolved in dimethyl sulfoxide or dimethyl sulfoxide as a negative control, for posterior examination under an epifluorescence microscope. The organic layer of the seven, 14 and 21-day cultures was analyzed by means of direct illumination with $365 \mathrm{~nm}$ UV light and by means of elution on G silica gel plate with hexane:ethyl acetate 1:4 unveiled with UV light. Results: All of the strains showed the presence of 6-AC (yellow fluorescence) and 6-hydroxylaminocoumarin (blue fluorescence) in thin layer chromatography, which explains the green fluorescence observed in the fungus structure. Conclusion: The nitroreductase activity is widely distributed in the S. schenckii complex and 6-NC is a fluorogenic substrate of easy access and applicability for the nitroreductase activity detection.
\end{abstract}

KEYWORDS: Sporotrichosis; Enzymatic activity; Fluorogenic substrate; 6-nitrocoumarin.

\section{INTRODUCTION}

Sporothrix schenckii is considered as a complex of species composed of S. brasiliensis, S. mexicana, S. globosa, S. schenckii sensu stricto and $S$. schenckii var. luriei ${ }^{17}$, thermal dimorphic pathogenic fungi that may usually be implanted through the skin causing a subcutaneous mycosis ${ }^{14,22}$. Classically, the infection is caused by traumatic inoculation with soil, and plants and organic matter contaminated with the fungus ${ }^{16}$. Some leisure and occupational activities, such as agriculture and floriculture, have been associated with the transmission of the disease $e^{4,11}$.

Chromogenic and fluorogenic substrates are useful tools for the research of enzymatic action. They facilitate purification and identification, as well as kinetic studies of the enzymes ${ }^{27}$. Although most chromogenic and fluorogenic substrates rely on known chromophores or fluorophores, there is still progress to be made in developing new aromatic systems as revealing groups ${ }^{13}$.

Nitroreductase is a member of a group of enzymes that reduces the wide range of nitroaromatic compounds and has potential industrial applications ${ }^{10,12,26}$. Nitroreductase activity has been detected in a diverse range of bacteria ${ }^{8,15,25}$ and in yeast ${ }^{9,28}$ by using chromogenic or fluorogenic substrates. For this purpose, nitrocoumarin represents a fluorogenic substrate class where the microbial nitroreductase activity produces several aminocoumarin derivatives, already used in several other enzyme assays.

The purpose of this work was the use of 6-NC as a novel fluorescent substrate to study its susceptibility to the intact cell system of $S$. schenckii, aiming to evaluate the nitroreductase activity in that fungus by the analysis of the reaction products formed in the culture media.

\section{MATERIALS AND METHODS}

6-Nitrocoumarin and 6-aminocoumarin synthesis: 6-Nitrocoumarin was prepared using the methodology described by MORGAN \& MICKLETHWAIT $(1904)^{18}$, then purified by column chromatography using silicagel (Merck), and then eluted with chloroform (Synth).

6-Aminocoumarin was obtained by the reduction of 6-nitrocoumarin with iron, under a standard procedure; it was purified by column chromatography with silicagel (Merck) and a gradient of ethyl acetatehexane (Synth). 
STOPIGLIA, C.D.O.; CARISSIMI, M.; DABOIT, T.C.; STEFANI, V.; CORBELLINI, V.A. \& SCROFERNEKER, M.L. - Application of 6-nitrocoumarin as a substrate for the fluorescent detection of nitroreductase activity in Sporothrix schenckii. Rev. Inst. Med. Trop. Sao Paulo, 55(5): 353-6, 2013.

The purity of the compounds was checked by Thin Layer Cromatography (TLC), and the structures were confirmed by the melting points and the usual spectroscopic techniques (IR, UV-Vis, ${ }^{1} \mathrm{H}-$ and $\left.{ }^{13} \mathrm{C}-\mathrm{NMR}\right)$.

Microorganisms: In this work, 33 clinical isolates of the $S$. schenckii complex, obtained in the Brazilian states of São Paulo, Rio Grande do Sul and Minas Gerais, and two strains reference (American Type Culture Collection - ATCC 201681 and 201679) from Rockville, MD, USA were utilized.

In situ analysis: The strains were cultured in potato dextrose agar (Difco) containing polysorbate 80 1\% (v/v) (Vetec). Each strain was inoculated in a microculture containing 6-nitrocoumarin or 6-aminocoumarin ( $\left.8 \times 10^{-2} \mathrm{~mol} / \mathrm{L}\right)$ dissolved in dimethyl sulfoxide (Vetec), or only dimethyl sulfoxide as a negative control. The strains were incubated for seven, 14 and 21 days at $35{ }^{\circ} \mathrm{C}$ and examined under an Epifluorescence Microscope - EFM (Nikon) with a UV-2A (330-380 nm) filter block.

Chromatographic analysis: The strains were cultured in Sabouraud dextrose agar (Difco) for five days in Roux flasks and then were treated with $100 \mathrm{~mL}$ of a solution of 6-nitrocoumarin $(1 \mathrm{mmol})$ in a sodium phosphate buffer $(10 \mathrm{mmol})$ and glucose $(4 \% \mathrm{w} / \mathrm{v})($ Synth), and incubated for seven, 14 and 21 days. Afterwards, the samples were treated with 100 $\mathrm{mL}$ of an aqueous saturated saline solution and extracted three times with chloroform ( $15 \mathrm{~mL}$ portion). The extract was concentrated in a rotary evaporator and analyzed by TLC (Silicagel), using hexane-ethyl acetate $(1: 4 \mathrm{v} / \mathrm{v})$ as the eluent, and visualized by UV light $(365 \mathrm{~nm})$. Controls were $6-\mathrm{NC}$ and $6-\mathrm{AC}$.

The crude product was dried with anhydrous sodium sulfate, purified by column chromatography using hexane-ethyl acetate $(1: 4 \mathrm{v} / \mathrm{v})$ as the eluent, and the reaction products were characterized by the usual spectroscopic techniques.

\section{RESULTS}

In situ analysis: All strains were able to reduce the 6-nitrocoumarin compound to generate significant levels of fluorescence when compared with the organism-free control (Fig. 1). There was no difference between the intensity of fluorescence produced in the different periods analyzed.

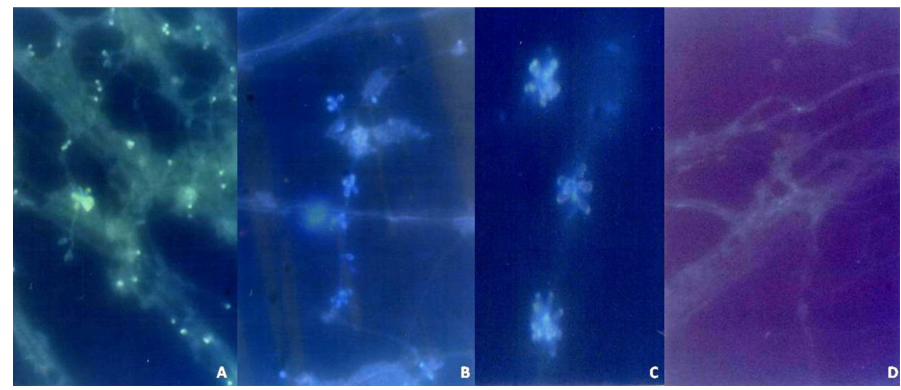

Fig. 1 - Fungal structures visualized under epifluorescence microscope: (A) 6-aminocoumarin substrate (positive control); (B) and (C) 6-nitrocoumarin substrate; (D) without substrate (negative control).
Chromatographic analysis: All the extracts obtained showed two bands: one corresponding to 6-aminocoumarin, and the other to 6-hydroxyaminocoumarin (Fig. 2).

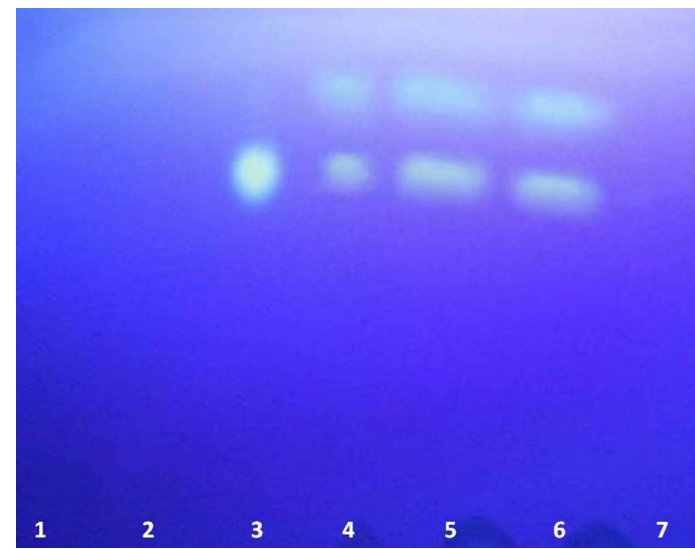

Fig. 2 - Thin Layer Cromatography carried out after incubation in different periods: (1) negative control; (2) 6-nitrocoumarin control; (3) 6-aminocoumarin control; extraction after incubation for (4) 7 days; (5) 14 days; (6) 21 days. (7): control of the absence of fungus growth.

\section{DISCUSSION}

In microbiology, the use of fluorescent compounds has found practical applications not only in the evaluation of cellular feasibility of yeast and spores, but also in the detection of bacterial growth and in the chemiotaxonomic differentiation of microorganisms ${ }^{9,23}$. In clinical specimens (biological liquids, skin biopsy and other tissues), these compounds have been used for the diagnosis of cutaneous, subcutaneous and systemic mycosis ${ }^{2,21}$.

Coumarin composes one class of heterocycles used as fluorofor and pigment for LASER. There has been a proposal for the use of coumarin as fluorogenic substrates for detecting the nitroreductase activity in bacteria and in yeast ${ }^{9,28}$.

The nitroreductase acts on aromatic nitro compounds not only in the presence, but also in the absence of oxygen ${ }^{1}$. The type I (oxygeninsensitive) catalyses the reduction of nitro groups, through sequential two-electron reductions, to nitroso, hydroxylamine intermediates and finally primary amines ${ }^{7,24}$; and the type II (oxygen-sensitive) catalyses one electron reduction of the nitro group, producing a nitro anion radical that subsequently reacts with oxygen, forming a superoxide radical and regenerating the original nitroaromatic compound ${ }^{20}$.

Metronidazole and related N-1 substitutes 5-nitroimidazoles like ornidazole, secnidazole and tinidazole are widely used in the treatment of diseases caused by protozoa and anaerobic bacteria ${ }^{19}$. It has been speculated that a reactive intermediate, formed in the microbial reduction of the 5-nitro group of nitroimidazoles, covalently binds to the DNA of the microorganism, triggering the lethal effect. Potential reactive intermediates include the nitroxide, nitroso, hydroxylamine and amine ${ }^{6}$. However, assays that were carried out have shown that S. schenckii is not responsive to metronidazole (data not shown). This fact emphasizes the necessity of testing different fluorogenic substrates for selecting a specific enzymatic activity, particularly the nitroreductase. 
STOPIGLIA, C.D.O.; CARISSIMI, M.; DABOIT, T.C.; STEFANI, V.; CORBELLINI, V.A. \& SCROFERNEKER, M.L. - Application of 6-nitrocoumarin as a substrate for the fluorescent detection of nitroreductase activity in Sporothrix schenckii. Rev. Inst. Med. Trop. Sao Paulo, 55(5): 353-6, 2013.

Through EFM it was possible to differentiate cell structures as hyphae, conidiophores and conidia. Compared to positive controls showing yellow fluorescence, the dye tested showed an intermediate blue fluorescence that was further investigated. Reduced 6-nitrocoumarin obtained better yield in fluorescence in reproductive cells, indicating that it is useful for a better visualization and identification of the species. GAZENKO et al. $(1998)^{5}$ observed that the comparison of the actinomycetes enzymatic activities of dormant spores with vegetative cells showed similarity of the enzymatic profiles, but higher activity for vegetative cells.

TLC eluted a sub-product with blue fluorescence, with a retention factor (Rf) value higher than aminocoumarin (yellow band), possibly related to the partial biological reduction of 6-nitrocoumarin. The investigation of the arylbenzothiazole, the benzoxazole and the benzimidazole derivatives as fluorogenic substrates for the detection of nitroreductase and aminopeptidase in Gram-negative and Gram-positive bacteria has shown differences of colonies fluorescence ${ }^{3}$. Similar to our study, they concluded that the origin of this effect has not yet been established, but may be a consequence of either the localization of the fluorophore in different regions of the organism or the result of further metabolic transformation of the initially formed fluorophore.

In this study, nitroreduction was active in all times of incubation tested, indicating a concurrent production of both reduction products. The results indicate that nitroreductase activity is widespread in this species. 6-NC has shown to be interesting as a fluorogenic substrate for the detection of nitroreductase activity and for a better visualization of Sporothrix schenckii reproductive cells. From the data obtained during this study, we intend to design a standard method for quantifying the nitroreductase activity, as well as for isolating the enzymes related to this activity.

\section{RESUMO}

\section{Aplicação de 6-nitrocumarina como substrato fluorescente para detecção de atividade nitroredutásica em Sporothrix schenckii}

Introdução: Sporothrix schenckii é um fungo dimórfico térmico, agente etiológico de micose subcutânea, a esporotricose. Nitrocumarina representa classe de substratos fluorogênicos em que a atividade nitroredutásica microbiana produz vários derivados, já utilizados em vários outros ensaios enzimáticos. O objetivo deste estudo foi analisar 6-nitrocumarina (6-NC) como substrato para estudo da atividade nitroredutásica em Sporothrix schenckii. Métodos: Trinta e cinco isolados de $S$. schenckii foram cultivados por sete, 14 e 21 dias a $35^{\circ} \mathrm{C}$ em um microcultivo contendo 6-nitrocumarina ou 6-aminocumarina (6-AC) solubilizada em dimetilsulfóxido ou dimetilsulfóxido como controle negativo, para posterior análise em microscópio de epifluorescência. A fase orgânica da cultura de sete, 14 e 21 dias foi analisada por meio de iluminação direta com luz UV de $365 \mathrm{~nm}$ e por eluição em placas de sílica gel G com hexano:acetato de etila 1:4 e revelada com luz UV. Resultados: Todos os isolados mostraram a presença de 6-AC (fluorescência amarela) e 6-hidroxilaminocumarina (fluorescência azul) em cromatografia em camada delgada, que explica a fluorescência verde observada na estrutura dos fungos. Conclusão: A atividade nitroredutásica é amplamente distribuída no complexo S. schenckii e 6-NC é um substrato fluorogênico de fácil obtenção e aplicabilidade para detecção da atividade nitroredutásica.

\section{ACKNOWLEDGEMENTS}

The authors also express their special thanks to Brazilian CAPES (Coordenação de Aperfeiçoamento de Pessoal de Nível Superior) and $\mathrm{CNPq}$ (Conselho Nacional de Desenvolvimento Científico e Tecnológico).

\section{REFERENCES}

1. Bryant C, De Luca M. Purification and characterization of an oxygen-insensitive NAD(P)H nitroreductase from Enterobacter cloacae. J Biol Chem. 1991;266:4119-25.

2. Carballo MG, Rodríguez NA, Peralta NB, de Cabalier ED. Application of direct fluorescence technique in the diagnosis of superficial mycosis. Rev Fac Cien Med Univ Nac Cordoba. 2002;59:57-61.

3. Cellier M, Fabrega OJ, Fazackerley E, James AL, Orenga S, Perry JD, et al. 2-Arylbenzothiazole, benzoxazole and benzimidazole derivatives as fluorogenic substrates for the detection of nitroreductase and aminopeptidase activity in clinically important bacteria. Bioorg Med Chem. 2011;19:2903-10.

4. da Rosa AC, Scroferneker ML, Vettorato R, Gervini RL, Vettorato G, Weber A. Epidemiology of sporotrichosis: a study of 304 cases in Brazil. J Am Acad Dermatol. 2005;52:451-9.

5. Gazenko SV, Reponen TA, Grinshpun SA, Willeke K. Analysis of airborne actinomycete spores with fluorogenic substrates. Appl Environ Microbiol. $1998 ; 64: 4410-5$.

6. Günay NS, Capan G, Ulusoy N, Ergenç N, Otük G, Kaya D. 5-Nitroimidazole derivatives as possible antibacterial and antifungal agents. Farmaco. 1999;54:826-31.

7. Haack T, Erdinger L, Boche G. Mutagenicity in Salmonella typhimurium TA98 and TA100 of nitroso and respective hydroxylamine compounds. Mutat Res. 2001;491:183-93.

8. Hannink N, Rosser SJ, French CE, Basran A, Murray JA, Nicklin S, et al. Phytodetoxification of TNT by transgenic plants expressing a bacterial nitroreductase. Nat Biotechnol. 2001;19:1168-72.

9. James AL, Perry JD, Jay C, Monget D, Rasburn JW, Gould FK. Fluorogenic substrates for the detection of microbial nitroreductases. Lett Appl Microbiol. 2001;33:403-8.

10. Kadiyala V, Nadeau LJ, Spain JC. Construction of Escherichia coli strains for conversion of nitroacetophenones to ortho-aminophenols. Appl Environ Microbiol. 2003;69:6520-6.

11. Kauffman CA, Hajjeh R, Chapman SW. Practice guidelines for the management of patients with sporotrichosis. For the Mycoses Study Group. Infectious Diseases Society of America. Clin Infect Dis. 2000;30:684-7.

12. Kitts CL, Green CE, Otley RA, Alvarez MA, Unkefer PJ. Type I nitroreductases in soil enterobacteria reduce TNT (2,4,6,-trinitrotoluene) and RDX (hexahydro-1,3,5trinitro-1,3,5-triazine). Can J Microbiol. 2000;46:278-82.

13. Krasovitskii BM, Bolotin BM. Organic luminescent materials: benzazoles. New York: VCH; 1988.

14. Lacaz CS, Porto E, Martins JEC, Heins-Vaccari EM, Melo NT. Micologia médica São Paulo: Sarvier; 2002.

15. Lee BU, Park SC, Cho YS, Kahng HY, Oh KH. Expression and characterization of the TNT nitroreductase of Pseudomonas sp. HK-6 in Escherichia coli. Curr Microbiol. 2008;56:386-90.

16. Lopes-Bezerra LM, Schubach A, Costa RO. Sporothrix schenckii and sporotrichosis. An Acad Bras Cienc. 2006;78:293-308. 
STOPIGLIA, C.D.O.; CARISSIMI, M.; DABOIT, T.C.; STEFANI, V.; CORBELLINI, V.A. \& SCROFERNEKER, M.L. - Application of 6-nitrocoumarin as a substrate for the fluorescent detection of nitroreductase activity in Sporothrix schenckii. Rev. Inst. Med. Trop. Sao Paulo, 55(5): 353-6, 2013.

17. Marimon R, Serena C, Gené J, Cano J, Guarro J. In vitro antifungal susceptibilities of five species of Sporothrix. Antimicrob Agents Chemother. 2008;52:732-4.

18. Morgan GT, Micklethwait FMG. 6-Aminocoumarin. J Chem Soc. 1904;85:1230-8.

19. Olender D, Zwawiak J, Lukianchuk V, Lesyk R, Kropacz A, Fojutowski A, et al. Synthesis of some N-substituted nitroimidazole derivatives as potential antioxidant and antifungal agents. Eur J Med Chem. 2009;44:645-52.

20. Oliveira IM, Zanotto-Filho A, Moreira JCF, Bonatto D, Henriques JAP. The role of two putative nitroreductases, Frm2p and $\mathrm{Hbn} 1 \mathrm{p}$, in the oxidative stress response in Saccharomyces cerevisiae. Yeast. 2010;27:89-102.

21. Ramos L, Mellado S, Ramadan S, Bulacio L, López C. Empleo de blanco de calcoflúor para el estudio de las especies de Malassezia por microscopia directa. Rev Argent Microbiol. 2006;38:4-8

22. Rippon JW. Sporotrichosis. In: Rippon JW. Medical mycology: the pathogenic fungi and the pathogenic actinomycetes. Philadelphia: W.B: Saunders; 1988

23. Santos RC, Faleiro NVS, Campo LF, Scroferneker ML, Corbellini VA, Rodembusch FS, et al. Synthesis and photophysical properties of novel succinimidyl benzazole derivatives, evaluated by Candida albicans ATCC 10231 fluorescent staining. Tetrahedron Lett. 2011;52:3048-53.
24. Sarlauskas J, Nemeikaite-Ceniene A, Anusevicius Z, Miseviciene L, Julvez MM, Medina M, et al. Flavoenzyme-catalyzed redox cycling of hydroxylamino and amino metabolites of 2,4,6-trinitrotoluene: implications for their cytotoxicity. Arch Biochem Biophys. 2004;425:184-92.

25. Smith AL, Erwin AL, Kline T, Unrath WC, Nelson K, Weber A, et al. Chloramphenico is a substrate for a novel nitroreductase pathway in Haemophilus influenzae. Antimicrob Agents Chemother. 2007;51:2820-9.

26. Vass SO, Jarrom D, Wilson WR, Hyde EI, Searle PF. E. coli NfsA: an alternative nitroreductase for prodrug activation gene therapy in combination with CB1954. Br J Cancer. 2009;100:1903-11.

27. Wahler D, Reymond JL. Novel methods for biocatalyst screening. Curr Opin Chem Biol. 2001;5:152-8.

28. Xu J, Yang Q, Qian X, Samuelsson J, Janson JC. Assessment of 4-nitro-1,8-naphthalic anhydride reductase activity in homogenates of bakers' yeast by reversed-phase highperformance liquid chromatography. J Chromatogr B Analyt Technol Biomed Life Sci. $2007 ; 847: 82-7$

Received: 25 October 2012

Accepted: 18 March 2013 